\title{
Thermal and strength performance of reinforced self-compacting concrete slabs mixed with basalt and PVA fibers in high intensity fire
}

\author{
Noraniza Mohd Jani ${ }^{1,3}$, Mohammad Shakir Nasif ${ }^{1,}{ }^{*}$, Nasir Shafiq $^{2}$, and William Pao $^{l}$ \\ ${ }^{1}$ Mechanical Engineering Department, Universiti Teknologi PETRONAS, 32610 Bandar Seri \\ Islander, Perak, Malaysia. \\ ${ }^{2}$ Civil Engineering Department, Universiti Teknologi PETRONAS, 32610 Bandar Seri Islander, \\ Perak, Malaysia. \\ ${ }^{3}$ Fire Science Research Group, 41050 Jalan Meru, Klang, Selangor, Malaysia.
}

\begin{abstract}
Fibers addition to concrete and the innovation of self-compacting concrete technology lead to the development of high-performance concrete. However, high intensity fire may adversely affect the performance of this type of concrete. A series of fire resistance test experiments to evaluate the performance of fiber reinforced self-compacting concrete (FRSCC) slabs consisting of various mix of basalt and PVA fibers were carried out by subjecting the concrete slabs as an element of construction to high intensity Hydrocarbon fire heating condition. The fire testing condition was in accordance with the standard time-temperature fire curve for 120 minutes up to $1100^{\circ} \mathrm{C}$ heating temperature. The temperatures on the surface and within the concrete slabs were recorded and the performance of each type of FRSCC slabs were evaluated. The performance of Basalt FR-SCC was found to be more resistant to fire in comparison to PVA FRSCC. There residual compressive strength of core samples were tested and SEM analysis were carried out to determine the effect of high intensity fire on the basalt and PVA FR-SCC slabs.
\end{abstract}

\section{Introduction}

The revolutionary and innovative development of self-compacting concrete (SCC) or selfconsolidating concrete leads to saving in skilled labor cost and faster construction time [1]. The normal concrete basically need to be compacted by using vibrator which required skilled labor workers. In comparison with SCC, it is an innovative concrete which does not requires vibration for compacting process. Thus fresh concrete could flow on its own and can achieve full compaction by itself. Modern application of high performance self-compacting concrete (SCC) is focused on high performance for better and more reliable quality, dense and uniform surface texture, improved durability, higher strength, and faster construction time. SCC technology has taken a further development since its original development in Japan, it specifications and design for better practical application of the SCC technology on its physical and mechanical characteristics, including mixing of fibers to enhance the properties of the SCC the same way as normal concrete [2].

*Corresponding Author: mohammad.nasif@utp.edu.my 
Under normal conditions, most concrete structures are subjected to a range of temperature no more severe than that imposed by ambient environmental conditions. Concrete is generally known for its capacity to endure high temperatures and fires, owing to its low thermal conductivity and high specific heat [3]. On the other hand, it does not mean that fire as well as higher temperatures does not affect the concrete properties. Characteristics such as color, compressive strength, elasticity, concrete density and surface appearance are affected by high temperature. Therefore, improving concrete's fire resistance is a field of interest for many researchers lately. According to their studies, it is possible to improve fire resistance of concrete in few ways including the addition of fibers to fresh concrete [3]. Basalt and polyvinyl alcohol (PVA) fiber-reinforced self-compacting concrete (FR-SCC) have been shown to enhance the mechanical properties at ambient conditions [4]; but its performance as a structural construction element in fire is yet to be assessed. There was no previous research done on the effects of basalt and PVA FR-SCCs' performance in accordance to standard fire i.e. for building fire (ISO Cellulosic Curve) and to rapid fire development (Hydrocarbon fire curve). The post-fire effects to the FR-SCC of basalt and PVA fibers also should be examined in order to assess the structural integrity of the FR-SCC which is the focus of this research.

\section{Fire exposure characteristics}

The type of fire, the fire size and heat output, have significant influence on the fire performance of a concrete structural system [5]. The researches pointed out that much of the current fire provisions contained in codes and standards are based on (standard ASTM E119 [6], BS 476-20 [7] ISO 834-1 [8] or similar) fire scenarios, which represents typical building fire. These provisions may not be directly applicable to fires resulting in infrastructure projects, offshore structures and tunnels due to a wide range of differences in fire characteristics. These fires, often referred to as hydrocarbon fires, typically represented by ASTM-E1529 Standard fire, much more severe than building fires and are characterised by fast heating rates or high fire intensities.

Considering, in a simplistic form, different fuel types and ventilation conditions, the following type of fire curves are considered for the testing of concrete slabs representing a typical fully developed compartmental building fire curve and a Hydrocarbon fire or liquid type fuel fire curve, referred to in ASTM E1529, BS 476-20: 1987 [6-7].

\section{Experimental materials and test procedure}

Considering the advantages offered by SCC compared to conventional concrete, experimental investigation have been carried out on the performance of fiber-reinforced selfcompacting concrete (FR-SCC) slabs without fiber, with Basalt fiber and PVA fiber in high intensity fire. The mix design adopted in this experiment on fiber reinforced self-compacting concrete [4] is shown in table 1.

Fire resistance is a property of materials that prevents or retards the passage of excessive heat or flames under conditions of use. For structural elements, it is defined as the ability of the element to confine a fire or to continue its structural function, or both, for a stated period of time. Two important parameters for evaluating fire resistance of a construction element are load-bearing capacity and integrity [9]. The later means that no large 
crack is produced in the separating element so that the fire and large heat can pass through it. Therefore, the loss of strength and cracking of the specimens are the important factors which are to be considered for evaluating the fire behavior of the test specimens.

The self-compacting concrete (SCC) slabs were casted between May and August 2016. The slabs were casted using a portable concrete mixer. Each SCC slab dimension is $1600 \mathrm{~mm}$ wide $\times 1600 \mathrm{~mm}$ long $\times 300 \mathrm{~mm}$ deep. The SCC slab was left to air- curing within the laboratory ambient condition for minimum 90 days prior to fire resistance testing.

Table 1. Design mix of fiber reinforced self-compacting concrete slabs text

\begin{tabular}{|c|c|c|c|c|c|c|c|c|c|}
\hline \multirow[t]{2}{*}{ Code Mix* } & \multirow{2}{*}{$\frac{\text { Cement }}{\mathrm{kg} / \mathrm{m}^{3}}$} & \multicolumn{2}{|c|}{\begin{tabular}{c|} 
Fine \\
Aggregate
\end{tabular}} & \multicolumn{2}{|c|}{\begin{tabular}{c|} 
Coarse \\
Aggregate
\end{tabular}} & Water & \multirow{2}{*}{\multicolumn{2}{|c|}{\begin{tabular}{c}
$\begin{array}{c}\text { Super } \\
\text { plasticizer }\end{array}$ \\
\multicolumn{1}{c}{$/ \mathrm{m}^{3}$}
\end{tabular}}} & $\begin{array}{c}\text { Fiber } \\
(P F-B F) \\
\end{array}$ \\
\hline & & $\mathrm{kg} / \mathrm{m}^{3}$ & $\mathrm{~kg} / \mathrm{m}^{3}$ & $\mathrm{~kg} / \mathrm{m}^{3}$ & $W / C$ & $\%$ & & & $\mathrm{~kg} / \mathrm{m}^{3}$ \\
\hline M1-0F & 600 & 900 & 750 & 200 & 0.33 & 2.0 & 12.0 & 0.0 & 0.0 \\
\hline M2- 1.0PF & 600 & 900 & 750 & 200 & 0.33 & 2.0 & 12.0 & 1.0 & 6.0 \\
\hline M3-1.0BF & 600 & 900 & 750 & 200 & 0.33 & 2.0 & 12.0 & 1.0 & 6.0 \\
\hline M4- 1.5PF & 600 & 900 & 750 & 200 & 0.33 & 2.0 & 12.0 & 1.5 & 9.0 \\
\hline M5- $1.5 \mathrm{BF}$ & 600 & 900 & 750 & 200 & 0.33 & 2.0 & 12.0 & 1.5 & 9.0 \\
\hline M6- 2.0PF & 600 & 900 & 750 & 200 & 0.33 & 2.0 & 12.0 & 2.0 & 12.0 \\
\hline M7-2.0BF & 600 & 900 & 750 & 200 & 0.33 & 2.0 & 12.0 & 2.0 & 12.0 \\
\hline
\end{tabular}

The fire resistance tests were carried out using an indicative fire resistance test furnace of nominal $1200 \mathrm{~mm} \times 1200 \mathrm{~mm}$ x $1200 \mathrm{~mm}$ chamber. The furnace temperature was measured by means of four (4) Type-K furnace thermocouples consisting of Type K thermocouple cable fixed to $12 \mathrm{~mm}$ diameter copper discs; arranged symmetrically in the furnace in two rows of two thermocouples.

The SCC slab was placed to cover a horizontal opening of the furnace chamber of $1200 \mathrm{~mm} \times 1200 \mathrm{~mm}$. The temperature of the unexposed face i.e. non-fire side of the SCC slab was measured by means of five (5) fixed surface calibrated specimen thermocouples consisting of Type $\mathrm{K}$ thermocouple cable fixed to $12 \mathrm{~mm}$ diameter copper discs and covered with $30 \mathrm{~mm}$ square millboard pads. The internal temperatures of the slab was measured by means of eleven (11) specimen thermocouples consisting of Type K thermocouple cable fixed to $12 \mathrm{~mm}$ diameter copper discs and placed within the slab during casting at every $25 \mathrm{~mm}$ deep interval.

The fire resistance tests were carried out in accordance to the general requirements of BS 476-20 [7]; and adopting the specific requirements of non-loadbearing horizontal element of construction in accordance to BS 476-22 [9]. During the testing, observations were taken on the behavior of the SCC slab. The duration of the fire testing was 120 minutes.

A total of eight (8) slabs were tested. One of the plain SCC slab (Code Mix M1-0F) was tested under the heating conditions of ISO Cellulosic Curve. Whilst, all seven (7) other slabs (all Code Mix M1 to M7) were subjected to the test under Hydrocarbon heating conditions.

\section{Test results and discussion}

The fire resistance tests were carried out between October 2016 and March 2017. All slabs were tested tor a period of 120 minutes.

All the tested slabs satisfied the performance for insulation and integrity performance in accordance the standards $[7,10]$. The standards describe the integrity as the ability of the test 
specimen to not collapse, not having any holes, cracks or fissures, and sustained flaming on the unexposed face which is the non-fire side. Whereas, insulation as the ability of the test specimen to restrict temperature rise of the unexposed face which is the non-fire side below the mean of $140 \mathrm{C}$ above the initial value.

A plain SCC slab (Code Mix M1) was tested to the Hydrocarbon curve had a rapid rise from the commencement of heating, whilst another plain SCC slab was tested to the ISO Cellulosic curve had a gentle temperature rise throughout the duration of the test.

Table 2. Comparison on temperatures of SCC slabs (Code Mix M1-0F) subjected to fire exposure under ISO Cellulosic curve and Hydrocarbon curve.

\begin{tabular}{|c|c|c|c|c|c|c|c|c|}
\hline $\begin{array}{l}\text { Time } \\
\text { (Mins) }\end{array}$ & $\begin{array}{c}\text { ISO } \\
\text { Cellulosic } \\
\text { Fire Curve } \\
\text { (Nominal) } \\
\left({ }^{\circ} \mathrm{C}\right)\end{array}$ & $\begin{array}{l}\text { Surface } \\
\text { of Slab } \\
\text { (Non- } \\
\text { fire } \\
\text { side) } \\
(\text { Mean) } \\
\left({ }^{\circ} \mathrm{C}\right)\end{array}$ & $\begin{array}{l}\text { Mid- } \\
\text { depth of } \\
\text { Slab } \\
\text { (Internal) } \\
\left({ }^{\circ} \mathrm{C}\right)\end{array}$ & $\begin{array}{c}25 \mathrm{~mm} \\
\text { from } \\
\text { bottom } \\
\text { slab } \\
(\text { Internal) } \\
\left({ }^{\circ} \mathrm{C}\right)\end{array}$ & $\begin{array}{c}\text { Hydrocarbon } \\
\text { Fire } \\
\text { Exposure } \\
\text { (Nominal) } \\
\left({ }^{\circ} \mathrm{C}\right)\end{array}$ & $\begin{array}{l}\text { Surface } \\
\text { of Slab } \\
\text { (Non- } \\
\text { fire } \\
\text { side) } \\
(\text { Mean) } \\
\left({ }^{\circ} \mathrm{C}\right)\end{array}$ & $\begin{array}{l}\text { Mid- } \\
\text { depth of } \\
\text { Slab } \\
\text { (Internal) } \\
\left({ }^{\circ} \mathrm{C}\right)\end{array}$ & $\begin{array}{c}25 \mathrm{~mm} \\
\text { from } \\
\text { bottom } \\
\text { slab } \\
(\text { Internal) } \\
\left({ }^{\circ} \mathrm{C}\right)\end{array}$ \\
\hline 0 & 20.0 & 31.9 & 30.1 & 30.5 & 44.0 & 30.94 & 29.5 & 30.6 \\
\hline 15 & 738.6 & 32.1 & 30.3 & 1721.0 & 1070.7 & 31.2 & 32.3 & 256.1 \\
\hline 30 & 841.8 & 32.3 & 37.5 & 312.0 & 1097.6 & 31.3 & 59 & 434.0 \\
\hline 45 & 902.3 & 32.3 & 58.5 & 414.0 & 1099.8 & 32.6 & 82.0 & 544.0 \\
\hline 60 & 945.3 & 33.3 & 73.5 & 476.0 & 1100.0 & 36.0 & 93.5 & 608.0 \\
\hline 75 & 978.7 & 36.7 & 85.0 & 528 & 1100.0 & 40.6 & 104.5 & 644.0 \\
\hline 90 & 1006.0 & 41.5 & 95.0 & 580 & 1100.0 & 45.6 & 115.5 & 672.0 \\
\hline 105 & 1029.1 & 46.2 & 102.5 & 628 & 1100.0 & 50.5 & 127.0 & 696.0 \\
\hline 120 & 1049.0 & 50.7 & 109.5 & 668 & 1100.0 & 54.9 & 139.0 & 716.0 \\
\hline
\end{tabular}

Table 3. Comparison on temperatures of Basalt FR-SCC slabs subjected to Hydrocarbon fire exposure.

\begin{tabular}{|c|c|c|c|c|c|c|c|c|c|c|}
\hline \multicolumn{2}{|c|}{ Code Mix } & \multicolumn{3}{|c|}{ M3-1.0BF } & \multicolumn{3}{c|}{ M5 } & \multicolumn{3}{|c|}{ M7 } \\
\hline $\begin{array}{c}\text { Time } \\
\text { Mins }\end{array}$ & $\begin{array}{c}\text { Hydro- } \\
\text { carbon } \\
\text { Fire } \\
\text { Exposure } \\
\left(\begin{array}{c}\text { Nominal }) \\
\left({ }^{\circ} \mathrm{C}\right)\end{array}\right.\end{array}$ & $\begin{array}{c}\text { Surface } \\
\text { of Slab } \\
(\mathrm{Mean}) \\
\left({ }^{\circ} \mathrm{C}\right)\end{array}$ & $\begin{array}{c}\text { Mid- } \\
\text { depth } \\
\text { of } \\
\text { Slab } \\
\left({ }^{\circ} \mathrm{C}\right)\end{array}$ & $\begin{array}{c}25 \mathrm{~mm} \\
\text { from } \\
\text { bottom } \\
\text { slab } \\
\left({ }^{\circ} \mathrm{C}\right)\end{array}$ & $\begin{array}{c}\text { Surface } \\
\text { of Slab } \\
(\mathrm{Mean}) \\
\left({ }^{\circ} \mathrm{C}\right)\end{array}$ & $\begin{array}{c}\text { Mid- } \\
\text { depth } \\
\text { of } \\
\text { Slab } \\
\left({ }^{\circ} \mathrm{C}\right)\end{array}$ & $\begin{array}{c}25 \mathrm{~mm} \\
\text { from } \\
\text { bottom } \\
\text { slab } \\
\left({ }^{\circ} \mathrm{C}\right)\end{array}$ & $\begin{array}{c}\text { Surface } \\
\text { of Slab } \\
(\mathrm{Mean}) \\
\left({ }^{\circ} \mathrm{C}\right)\end{array}$ & $\begin{array}{c}\text { Mid } \\
\text { depth } \\
\text { of } \\
\text { Slab } \\
\left({ }^{\circ} \mathrm{C}\right)\end{array}$ & $\begin{array}{c}25 \mathrm{~mm} \\
\text { from } \\
\text { bottom } \\
\text { slab } \\
\left({ }^{\circ} \mathrm{C}\right)\end{array}$ \\
\hline 0 & 44.0 & 28.6 & 27.8 & 28.5 & 28.54 & 28.7 & 29.4 & 30.46 & 29.6 & 30.9 \\
\hline 15 & 1070.7 & 28.96 & 27.9 & 114 & 28.72 & 28.8 & 171 & 30.58 & 29.8 & 87 \\
\hline 30 & 1097.6 & 28.86 & 30.9 & 191 & 28.88 & 33 & 316.1 & 30.26 & 32.8 & 146 \\
\hline 45 & 1099.8 & 29.16 & 41.5 & 282 & 29.04 & 46.5 & 428 & 29.86 & 43 & 205 \\
\hline 60 & 1100.0 & 30.86 & 55 & 352 & 30.42 & 60.5 & 504 & 29.98 & 54.5 & 260 \\
\hline 75 & 1100.0 & 33.68 & 66 & 408 & 32.9 & 70.5 & 556 & 30.92 & 64.5 & 304 \\
\hline 90 & 1100.0 & 37.86 & 74 & 452 & 36.3 & 78.5 & 600 & 32.9 & 72 & 340 \\
\hline 105 & 1100.0 & 42.46 & 84 & 488 & 39.8 & 85 & 628 & 35.54 & 78 & 370 \\
\hline 120 & 1100.0 & 46.92 & 92 & 516 & 43.46 & 90 & 656 & 38.56 & 83 & 396 \\
\hline
\end{tabular}

Under ISO fire, after 8 minutes of fire testing the temperature at $25 \mathrm{~mm}$ from the exposed face of slab only starting to reach $100^{\circ} \mathrm{C}$. At the termination of test at 120 minutes of testing, the temperature at the depth of slab was $668^{\circ} \mathrm{C}$. At termination of test, the temperature of the slab at $150 \mathrm{~mm}$ deep from the unexposed face was still below $100^{\circ} \mathrm{C}$. The surface temperature of the non-fire side was $53.3^{\circ} \mathrm{C}$. 
Under Hydrocarbon (HC) fire Table 2 shows the tabulation of temperatures for plain SCC under ISO Cellulosic and Hydrocarbon fire exposure. Table 2 shows the actual mean furnace temperatures, the slabs' temperatures on the surface of the non-fire side.

The plain SCC slab that was subjected to Hydrocarbon fire was found to be having higher temperature near to the bottom of the slab by slightly $48 \mathrm{C}$ only. The non-fire side surface temperature also only showed slightly higher for the slab exposed to Hydrocarbon fire.

After these findings, all the Basalt and PVA fiber reinforced self-compacting concrete were subjected only to Hydrocarbon fire which have more severe effects to the slabs.

Tables 3 and 4 provide comparison of the Basalt and PVA fibers reinforced selfcompacting concrete slabs when subjected to Hydrocarbon fire for 120 minutes.

All the Basalt and PVA fibers fiber reinforced self-compacting concrete slabs had surface temperature below $50^{\circ} \mathrm{C}$ at the termination of fire testing after 120 minutes of exposure to Hydrocarbon fire.

Table 4. Comparison on temperatures of PVA FR-SCC slabs subjected to Hydrocarbon fire exposure

\begin{tabular}{|c|c|c|c|c|c|c|c|c|c|c|}
\hline \multicolumn{2}{|c|}{ Code Mix } & \multicolumn{3}{|c|}{ M2-1.0PF } & \multicolumn{3}{c|}{ M4-1.5PF } & \multicolumn{3}{c|}{ M6-2.0PF } \\
\hline $\begin{array}{c}\text { Time } \\
\text { Mins }\end{array}$ & $\begin{array}{c}\text { Hydrocarbon } \\
\text { Fire } \\
\left(\begin{array}{c}\text { Nominal }) \\
\left({ }^{\circ} \mathrm{C}\right)\end{array}\right.\end{array}$ & $\begin{array}{c}\text { Surface } \\
\text { of Slab } \\
(\mathrm{Mean}) \\
\left({ }^{\circ} \mathrm{C}\right)\end{array}$ & $\begin{array}{c}\text { Mid } \\
\text { depth } \\
\text { of } \\
\text { Slab } \\
\left({ }^{\circ} \mathrm{C}\right)\end{array}$ & $\begin{array}{c}25 \mathrm{~mm} \\
\text { from } \\
\text { bottom } \\
\text { slab } \\
\left({ }^{\circ} \mathrm{C}\right)\end{array}$ & $\begin{array}{c}\text { Surface } \\
\text { of Slab } \\
(\mathrm{Mean}) \\
\left({ }^{\circ} \mathrm{C}\right)\end{array}$ & $\begin{array}{c}\text { Mid- } \\
\text { depth } \\
\text { of } \\
\text { Slab } \\
\left({ }^{\circ} \mathrm{C}\right)\end{array}$ & $\begin{array}{c}25 \mathrm{~mm} \\
\text { from } \\
\text { bottom } \\
\text { slab } \\
\left({ }^{\circ} \mathrm{C}\right)\end{array}$ & $\begin{array}{c}\text { Surface } \\
\text { of Slab } \\
(\mathrm{Mean}) \\
\left({ }^{\circ} \mathrm{C}\right)\end{array}$ & $\begin{array}{c}\text { Mid- } \\
\text { depth } \\
\text { of } \\
\text { Slab } \\
\left({ }^{\circ} \mathrm{C}\right)\end{array}$ & $\begin{array}{c}25 \mathrm{~mm} \\
\text { from } \\
\text { bottom } \\
\text { slab } \\
\left({ }^{\circ} \mathrm{C}\right)\end{array}$ \\
\hline 0 & 44 & 28.3 & 27.8 & 28.1 & 32.08 & 30.9 & 31.2 & 29.78 & 29.7 & 30.1 \\
\hline 15 & 1070.6 & 28.36 & 28.2 & 229.2 & 32.38 & 31 & 162 & 29.84 & 30.1 & 428.2 \\
\hline 30 & 1097.5 & 28.66 & 45.5 & 458.2 & 32.6 & 51.5 & 312.1 & 30.08 & 47.3 & 648 \\
\hline 45 & 1099.8 & 29 & 72.5 & 560 & 32.68 & 85.5 & 430 & 30.14 & 70 & 736 \\
\hline 60 & 1099.9 & 29.94 & 86 & 624 & 33.52 & 97 & 516 & 30.68 & 84.5 & 788 \\
\hline 75 & 1099.9 & 31.88 & 94 & 688.1 & 35.16 & 99 & 584 & 31.92 & 94.5 & 844 \\
\hline 90 & 1100 & 34.76 & 97 & 720 & 38.5 & 99.5 & 624 & 34.26 & 102.5 & 868 \\
\hline 105 & 1100 & 38.02 & 99 & 672.7 & 42.42 & 100.5 & 656 & 38.04 & 109.6 & 880 \\
\hline 120 & 1100 & 41.38 & 101 & 686.1 & 46.48 & 108.5 & 680 & 41.98 & 117.5 & 883.9 \\
\hline
\end{tabular}

Table 5. Comparison of average compressive strength of various design mix.

\begin{tabular}{|c|c|c|c|c|}
\hline \multirow{2}{*}{ Code Mix } & \multicolumn{2}{|c|}{ Compressive Strength $(\mathrm{MPa})$} & \multirow{2}{*}{$\begin{array}{c}\text { Reduction of } \\
\text { Compressive } \\
\text { Strength }(* \%)\end{array}$} & Type of Fire \\
\cline { 2 - 3 } & Non-Fire & Fire Tested & 13.4 & ISO Cellulosic \\
\hline M1-0F & 68.7 & 59.5 & 21.0 & Hydrocarbon \\
\hline M1-0F & 68.7 & 54.2 & 38.8 & Hydrocarbon \\
\hline M2-1.0PF & 80.0 & 48.9 & 34.0 & Hydrocarbon \\
\hline M3-1.0BF & 48.4 & 31.9 & 22.6 & Hydrocarbon \\
\hline M4-1.5PF & 70.8 & 54.8 & 21.3 & Hydrocarbon \\
\hline M5-1.5BF & 46.2 & 36.4 & 27.9 & Hydrocarbon \\
\hline M6-2.0PF & 69.7 & 50.2 & 27.3 & Hydrocarbon \\
\hline M7-2.0BF & 45.3 & 32.9 & & \\
\hline
\end{tabular}

After the fire tests, three (3) core samples of 100nn diameter were taken from each fire tested slabs and the control non-fire test slabs for the determination of compressive strength as shown in Table 5. 
From the fire test results, Basalt FR-SCC Code Mix M7 with 2\% Basalt fiber showed the best performance among all design mix when tested under high intensity Hydrocarbon fire.

It is found from the results presented that the best design mix when tested under Hydrocarbon fire was found to be basalt fibers reinforced self-compacting concrete with $2 \%$ basalt fiber percentage.

\section{Conclusion}

The fire resistance performance of fiber self-compacting concrete (FRSCC) with $2.0 \%$ basalt fiber (Code Mix M7 2.0BF) demonstrated the best among all tested design mixes when subjected to Hydrocarbon fire. The PVA FRSCC with 2\% fibers (Code Mix M6 2.0PF) was found to have the least fire resistance performance compared to all FRSCC design mixes tested. Code Mix 6 was found to have higher temperature recorded by $167.9^{\circ} \mathrm{C}$ compared to the plain SCC when subjected to Hydrocarbon fire exposure. Whereas, basalt and PVA FRSCC of $1.5 \%$ were found to have slightly better fire resistance performance compared to plain SCC when subjected to exposure under Hydrocarbon fire. In terms of residual compressive strength when the basalt and PVA FR-SCCs' compressive residual strength compared to the plain SC exposed to Hydrocarbon fire, the $1.5 \%$ showed the most reduction in compressive strength i.e. by $22.6 \%$ and $21.3 \%$ respectively. Finding the balance of the fibers percentage and the fire resistance performance and its effects after fire in terms of residual compressive strength, both basalt and PVA mix of $1.5 \%$ were found to provide good fire resistance performance and higher residual compressive strength.

\section{Acknowledgment}

The authors are gratefully acknowledging Fire Science Research Group (FSRG) support to this research for the usage of the fire resistance test furnace. The authors also gratefully acknowledge the financial support by Promat (Malaysia) S/B.

\section{References}

1. H. Okamura, M. Ouchi, Jr. of Adv. Conc. Tech., 1(1), pp.5-15, (2003).

2. EFNARC, Specification and Guidelines for Self-Compacting Concrete, (EFNARC, 2002).

3. O. Arioz, Fire Safety Jr., 42, pp. 516-522, (2007).

4. A. F. Mohamed Salih, Performance of fibreorced self-compacting concrete containing different pozzolanic material. (Phd. Dissertation., Universiti Teknologi Petronas, 2014).

5. V. Kodur, L. Phan, Fire Safety Jr. 42, pp. 482-488., (2007).

6. ASTM, ASTM E119-98, Standard Test Method for Fire Tests for Building Construction and Materials, (American Society for Testing and Materials, 1998)

7. BSI, British Standard BS476, Part 20: Method for determination of the fire resistance of elements of construction, (British Standards Institution, London, 1987).

8. ISO, ISO 834-1, Fire Resistance Tests Elements of Building Construction, (International Organisation for Standardization, Geneva, 1999).

9. BSI, BS 476-22, Part 22. Method for determination of non-loadbearing elements of construction, (British Standards Institution, London, 1987). 